Annals of Warsaw University of Life Sciences - SGGW

Land Reclamation No 50 (2), 2018: 119-128

(Ann. Warsaw Univ. of Life Sci. - SGGW, Land Reclam. 50 (2), 2018)

\title{
Stress-dilatancy of gravel for triaxial compression tests
}

\section{ZENON SZYPCIO}

Faculty of Civil and Environmental Engineering, Bialystok University of Technology, Poland

\begin{abstract}
Stress-dilatancy of gravel for triaxial compression tests. The stress-plastic dilatancy relationships for gravel are analyzed based on drained triaxial tests experiments described in literature. For this, Frictional State Theory is used. The characteristic points and stages of shearing may be defined from the analysis of $\eta-D^{p}$ relationship. The characteristic points and stages of shearing cannot be identified from ordinary stress-strain, volumetric strain-shear strain relationships that are shown in literature.
\end{abstract}

Key words: granular soils, gravel, dilatancy, frictional state

\section{INTRODUCTION}

The construction of embankments and light structures on soft soils has been a challenge to geotechnical community in the last decades. A widely employed technique for the improvement of weak soils is the installation of stone columns or encased stone columns in it. Gravel is generally used as a forming material (Bergado and Lam 1987, Castro et al. 2013, Miranda and Da Costa 2016, Miranda 2017). Gravel is also used for the construction of dams (Liu 2009). The proper description of stress-strain behaviour is very important for designers. Gravel is a uniformly graded uncemented material with the diameter of grains ranging between 2 and $63 \mathrm{~mm}$. Little information is available in literature dealing with the influence of density and stress level on the stress - strain behaviour of gravel (Cimentada et al. 2011, Hong 2012, Castro et al. 2013, Miranda and Da Costa 2016).

The newly developed Frictional State Theory gives possibilities for describing stress-dilatancy behaviour of soils at different stages of shearing (Szypcio 2016a). In this paper the experimental data from drained triaxial compression tests conducted by Castro et al. (2013), Miranda et al. (2015), and Miranda and Da Costa (2016) will be analyzed. The tests were performed on gravel samples of different densities and different confining cell pressures.

It will be shown that characteristic behaviour of granular soils may be described by the use of Frictional State Theory (Szypcio 2016a).

\section{STRESS-PLASTIC DILATANCY RELATIONSHIP}

The stress-plastic dilatancy relationship for soils has a form (Szypcio 2016a, b):

$\eta=Q-A D^{p}$ 
For drained triaxial compression:

$$
\eta=q / p^{\prime}
$$$$
Q=M^{\circ}-\alpha A^{\circ}
$$$$
A=\beta A^{\circ}
$$$$
M^{\circ}=\frac{6 \sin \Phi^{\circ}}{3-\sin \Phi^{\circ}}
$$$$
A^{\circ}=1-\frac{1}{3} M^{\circ}
$$$$
q=\sigma_{1}^{\prime}-\sigma_{3}^{\prime}
$$$$
p^{\prime}=\frac{1}{3}\left(\sigma_{1}^{\prime}+2 \sigma_{3}^{\prime}\right)
$$$$
D^{p}=\frac{\delta \varepsilon_{v}^{p}}{\delta \varepsilon_{q}^{p}}
$$$$
\delta \varepsilon_{v}^{p}=\delta \varepsilon_{1}^{p}+2 \delta \varepsilon_{3}^{p}
$$$$
\delta \varepsilon_{q}^{p}=\frac{2}{3}\left(\delta \varepsilon_{1}^{p}-\delta \varepsilon_{3}^{p}\right)
$$

where:

$\Phi^{\circ}$ - critical frictional state angle;

$\alpha, \beta$ - frictional state theory parameters.

The plastic parts of volumetric and shear strain increments are calculated from equations:

$$
\begin{aligned}
& \delta \varepsilon_{v}^{p}=\delta \varepsilon_{v}-\delta \varepsilon_{v}^{e} \\
& \delta \varepsilon_{q}^{p}=\delta \varepsilon_{q}-\delta \varepsilon_{q}^{e}
\end{aligned}
$$

where:

$$
\begin{aligned}
& \delta \varepsilon_{v}^{e}=\frac{\delta p^{\prime}}{K} \\
& \delta \varepsilon_{q}^{e}=\frac{\delta q}{3 G}
\end{aligned}
$$

The bulk $(K)$ and shear $(G)$ will be calculated from the data of the initial state of shearing later.

CHARACTERISTIC

STRESS-PLASTIC DILATANCY RELATIONSHIP DURING SHEAR

The characteristic stress-plastic dilatancy relationships which may be observed for granular unbounded material differ for four stages of shear, which is shown in Figure 1.

At the initial stage of shearing the stress grows very quickly. The behaviour of granular material is purely elastic or quasi elastic. The global volumetric and shear strain increments are equal or almost equal to elastic ones. Therefore, the plastic parts of volumetric and shear strain increments are equal to or almost zero. The plastic dilatancy $\left(D^{p}\right)$ from equation (2.h) cannot be calculated. At this stage of shearing Frictional State Theory cannot be used, and usually for $0 \leq \varepsilon_{a}$ $\leq 0.1-0.15 \%$ (Coop and Willson 2003, Dołżyk-Szypcio 2018) the value of tangent stiffness shear modulus $\left(G_{t}\right)$ is almost constant for low stress level or small drops with axial shear for higher stress level and may be assumed:

$G \approx G_{t}$

The tangent stiffness bulk shear modulus may be calculated from the following equation:

$K_{t}=\frac{2}{3} \frac{1+v_{t}}{1-2 v_{t}} G_{t}$

where: $v_{t}-$ stiffness Poisson's ratio. 


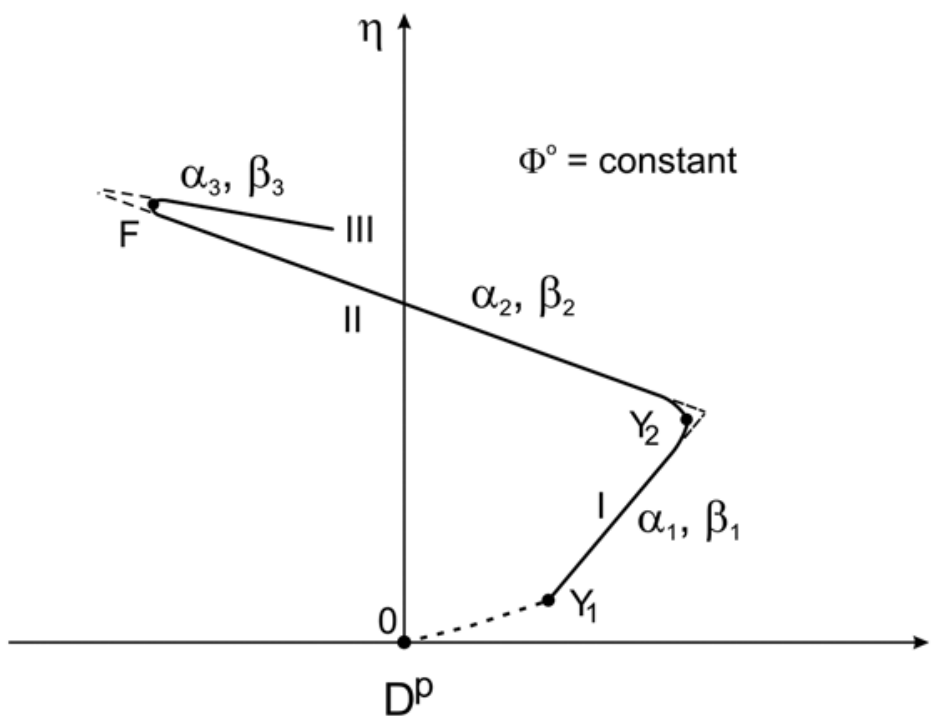

FIGURE 1. Characteristic stress-plastic dilatancy relationships

The tangent stiffness shear modulus $\left(G_{t}\right)$ and Poisson's ratio $\left(v_{t}\right)$ for conventional $\left(\delta \sigma_{3}^{\prime}=0\right)$ drained triaxial tests may be calculated from the following equations:

$G_{t}=\frac{\delta q}{3 \delta \varepsilon_{q}}$

$v_{t}=\frac{3-2\left(\delta \varepsilon_{v} / \delta \varepsilon_{q}\right)}{6+3\left(\delta \varepsilon_{v} / \delta \varepsilon_{q}\right)}$

The point $\mathrm{Y}_{1}$ (Fig. 1) represents the onset of gross yielding - stage I of shearing. The plastic parts of volumetric and shear strains increments are small. The high value of plastic dilatancy calculated from equation (2.h) suddenly appeared. For low stress level such value of plastic dilatancy is negative (material dilates) but for higher stress level it is positive (material contracts). The point $\mathrm{Y}_{2}$ represents the final part of this stage of defor- mation, which is before the transitional point, where the material starts to dilate.

At this stage of shearing the value of tangent stiffness shear modulus drops quickly from values at point $\mathrm{Y}_{1}$ to very small (almost zero) values at point $\mathrm{Y}_{2}$ (Coop and Willson 2003). The unexpected relationship between stress ratio and plastic dilatancy $\left(\eta-D^{p}\right)$ may be approximated by a straight line (1) defined by $\Phi^{\circ}, \alpha_{1}$ and $\beta_{1}$.

At the next stage (stage II) of shearing the elastic part of volumetric and shear strain increments are slightly relative to global ones. So, at this stage of shearing $\delta \varepsilon_{v}{ }^{p}=\delta \varepsilon_{v}$ and $\delta \varepsilon_{q}{ }^{p}=\delta \varepsilon_{q}$, which may be assumed as ordinary. The stress ratio-plastic dilatancy may be also approximated by a straight line defined by $\Phi^{\circ}$, $\alpha_{2}$ and $\beta_{2}$. At this stage of shearing the intensive rearrangement of grains may be observed. The value of plastic dilatancy is a function of initial density and stress level. The maximum absolute value of 
plastic dilatancy for dilative materials is accompanied by maximum value of stress ratio. In Figure 1 this point is signed as point $F$ (failure point). Generally, at this point a shear band is formed and nonhomogeneous deformation is observed in the sheared sample. For most sands failure points are located on the frictional state line defined by $\Phi^{\circ}, \alpha=0$ and $\beta=1.0$ (Szypcio 2016a). Due to grain breakage, experimental instability and other unknown reasons point $\mathrm{F}$ does not lie on the frictional state line (Dołżyk-Szypcio 2018). For contracting material during shear at this stage the maximum value of plastic dilatancy vanishes $\left(D^{p}=0\right)$, the structure of soil is fully destroyed $(\alpha=0)$ and critical frictional state is reached at high values of axial strains (about 30\%). The post-peak (stage III) of shearing generally shows unstable behaviour. The stress values quickly drops during shear. Only for some experiments the stress ratio-plastic dilatancy may be properly approximated by a straight line defined by $\Phi^{\circ}, \alpha_{3}, \beta_{3}$ (Fig. 1). For materials with large size grains (Miranda and Da Costa 2016, Dołżyk-Szypcio 2018) the stable state with $D^{p}=0$ and $\eta=M$ may be achieved only for some experiments. The achieved values of $M$ are functions of stress level and initial density (Dołżyk-Szypcio 2018). So, using critical state framework for these soils is problematic. The values of secant shear modulus are ordinarily negative.

\section{THE TESTED GRAVEL}

The gravel tested by Castro et al. (2013), Miranda et al. (2015) and Miranda and Da Costa (2016) was uniformly graded limestone gravel with particle sizes between 4 and $5 \mathrm{~mm}$. The tests were conducted at drained conditions and constant confining pressure. The samples were prepared at different initial densities (density ratio $-D_{r}$ ). A lower density was achieved by pouring. A higher density was achieved by placing gravel in several layers and compacting each layer using the same energy. The initial conditions of tests are summarized in Table 1.

\section{CALCULATION METHOD}

Some triaxial tests relationships $q-\varepsilon_{a}$ and $\varepsilon_{v}-\varepsilon_{a}$ were sectionally approximated by high degree polynomials. The values of tangent stiffness shear modulus $\left(G_{t}\right)$ and Poisson's ratios $\left(v_{t}\right)$ were calculated with equations (7) and (8) respectively.

TABLE 1. Tests conditions

\begin{tabular}{|c|c|c|c|c|c|}
\hline \multicolumn{2}{|c|}{ Castro et al. (2013) } & \multicolumn{2}{|c|}{ Miranda et al. (2015) } & \multicolumn{2}{|c|}{ Miranda and Da Costa (2016) } \\
\hline $\begin{array}{r}\mathrm{D}_{\mathrm{r}} \\
(\%)\end{array}$ & $\begin{array}{c}\sigma_{c} \\
(\mathrm{kPa}) \\
\end{array}$ & $\begin{array}{c}D_{\mathrm{r}} \\
(\%) \\
\end{array}$ & $\begin{array}{c}\sigma_{c} \\
(\mathrm{kPa})\end{array}$ & $\begin{array}{c}\mathrm{D}_{\mathrm{r}} \\
(\%) \\
\end{array}$ & $\begin{array}{c}\sigma_{c} \\
(\mathrm{kPa})\end{array}$ \\
\hline \multirow{5}{*}{100} & 50 & \multirow{5}{*}{35} & 50 & \multirow{5}{*}{50} & 25 \\
\hline & 100 & & 150 & & 50 \\
\hline & 200 & & 300 & & 150 \\
\hline & 300 & & - & & 300 \\
\hline & 400 & & - & & - \\
\hline
\end{tabular}


The values $G=G_{t}$ and $v=v_{t}$ at the start of shearing $\left(\varepsilon_{a} \approx 0\right)$ were accepted for calculations. The values $G$ and $v$ taken for the analysis are shown in Table 2 . At stage I (elastic/quasi elastic) the plastic parts of volumetric and shear strain increments are very small (almost zero) and plastic dilatancy cannot be calculated correctly.

For later stages of shearing the plastic parts of volumetric and shear strain increments were calculated with use of equations (2.i) and (2.j) respectively for small increments of axial strains. So, experimental relationship $\eta-D^{p}$ were founded for each test. For stages I, II, III of shearing experimental relationships $\eta-D^{p}$ were approximated by linear relationships defined by angle $\Phi^{\circ}$ and parameters $\alpha$ and $\beta$. The linear relationships for stage II intercept $\eta$ axis almost at the same values for all the tests, independent of initial density and stress level. The accepted mean value of interceptions is $\eta=M^{\circ}=1.6$ so the value of $\Phi^{\circ}=39.2^{\circ}$ is calculated with equation (2.d). For the accepted value of $\Phi^{\circ}$ the parameters $\alpha_{1}, \beta_{1}$ for stage I and parameters $\alpha_{2}, \beta_{2}$ for stage II were fixed and shown in Table 2. Some experiments were interrupted before reaching stage III (post-failure) and parameters $\alpha_{3}, \beta_{3}$ cannot be calculated.

If post-failure shearing was performed, the experimental relationship $\eta-D^{p}$ may be approximated by a straight line and parameters $\alpha_{3}, \beta_{3}$ may be appointed.

The characteristic points $\mathrm{Y}_{1}, \mathrm{Y}_{2}$ and $\mathrm{F}$ can be simply identified with $\eta-D^{p}$ relationships for each tests (Figs. 2d, 3d and 4d). The characteristic points are shown in Figures 2, 3 and 4 for relationships $q-\varepsilon_{a}, \varepsilon_{v}-\varepsilon_{a}$ and $G_{t}-\varepsilon_{a}$. The characteristic points for $\eta-D^{p}$ relationship are not characteristic for $q-\varepsilon_{a}, \varepsilon_{v}-\varepsilon_{a}$ relationships ordinarily shown in literature. The points $Y_{1}$ and $Y_{2}$ are characteristic for $G_{t}-\varepsilon_{a}$ relationship. At point $\mathrm{Y}_{1}$ values $G_{t}$ onset quickly drop. At point $\mathrm{Y}_{2}, G_{t}$ reaches small, nearly zero values. It is simply visible that elastic/quasi elastic stage is realized only at the initial phase

TABLE 2. Elastic and frictional state parameters

\begin{tabular}{|c|c|c|c|c|c|c|c|c|c|c|}
\hline Test & $\begin{array}{l}D_{\mathrm{r}} \\
(\%)\end{array}$ & $\begin{array}{c}\sigma_{c} \\
(\mathrm{kPa})\end{array}$ & $\begin{array}{c}G \\
(\mathrm{MPa})\end{array}$ & $\begin{array}{l}v \\
(-)\end{array}$ & $\alpha_{1}$ & $\beta_{1}$ & $\alpha_{2}$ & $\beta_{2}$ & $\alpha_{3}$ & $\beta_{3}$ \\
\hline \multirow{3}{*}{$\begin{array}{c}\text { Miranda } \\
\text { et al. } \\
(2015)\end{array}$} & \multirow{3}{*}{35} & 50 & 8.75 & 0.245 & -4.00 & 9.50 & -0.05 & 1.80 & - & - \\
\hline & & 150 & 21.1 & 0.077 & -4.70 & 7.50 & -0.02 & 1.70 & - & - \\
\hline & & 300 & 26.7 & 0.003 & -1.80 & 3.60 & -0.10 & 1.90 & - & - \\
\hline \multirow{4}{*}{$\begin{array}{c}\text { Miranda } \\
\text { and Da } \\
\text { Costa } \\
(2016)\end{array}$} & \multirow{4}{*}{50} & 25 & 6.20 & 0.32 & 1.80 & 12.0 & 0.00 & 2.30 & -1.60 & -0.60 \\
\hline & & 50 & 6.05 & 0.21 & -1.10 & 8.50 & 0.10 & 2.20 & -0.85 & 0.00 \\
\hline & & 150 & 11.75 & 0.04 & -1.00 & 5.00 & 0.13 & 2.90 & - & - \\
\hline & & 300 & 18.25 & 0.03 & -1.95 & 4.50 & 0.00 & 2.30 & - & - \\
\hline \multirow{3}{*}{$\begin{array}{l}\text { Castro et } \\
\text { al. (2013) }\end{array}$} & \multirow{3}{*}{100} & 50 & 12.10 & 0.18 & 2.50 & 7.50 & -0.05 & 1.70 & - & - \\
\hline & & 100 & 13.60 & 0.15 & -0.20 & 6.50 & 0.00 & 1.60 & -0.75 & 0.00 \\
\hline & & 400 & 35.26 & 0.10 & -0.30 & 3.00 & -0.10 & 1.70 & 0.00 & 1.70 \\
\hline
\end{tabular}



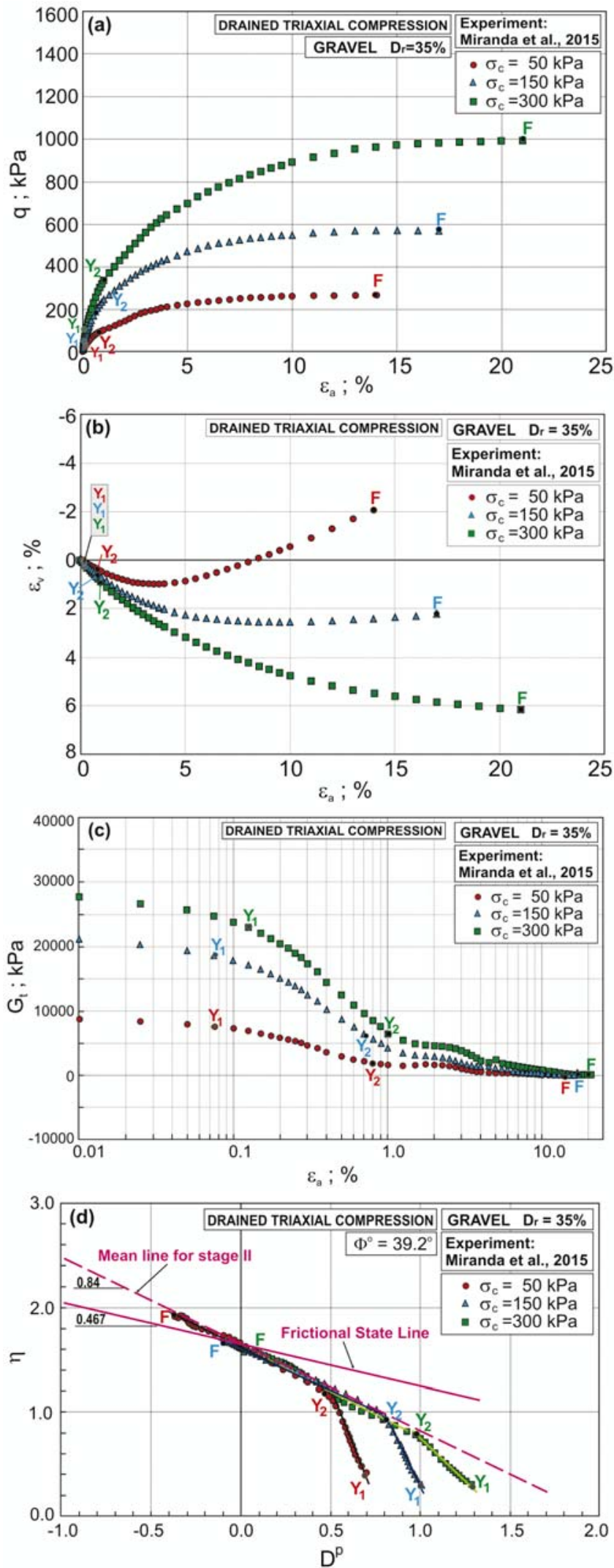

FIGURE 2. Relationships for loose gravel: $\mathrm{a}-q-\varepsilon_{a} ; \mathrm{b}-\varepsilon_{v}-\varepsilon_{a} ; \mathrm{c}-G_{t}-\varepsilon_{a}$; $\mathrm{d}-\eta-D^{p}$ 

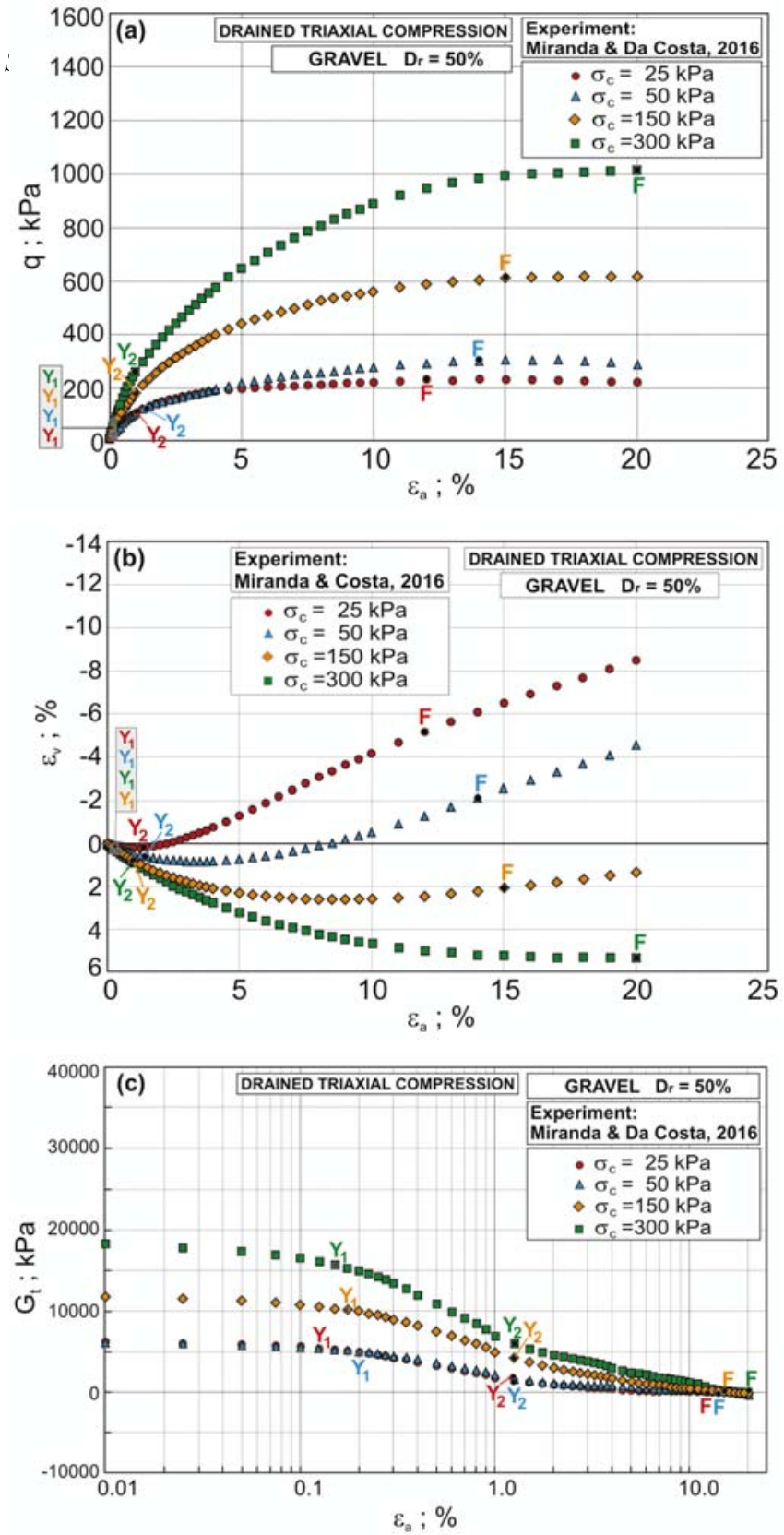

FIGURE 3. Relationships for medium dense gravel: $\mathrm{a}-q-\varepsilon_{a} ; \mathrm{b}-\varepsilon_{v}-\varepsilon_{a}$; $\mathrm{c}-G_{t}-\varepsilon_{a} ; \mathrm{d}-\eta-D^{p}$

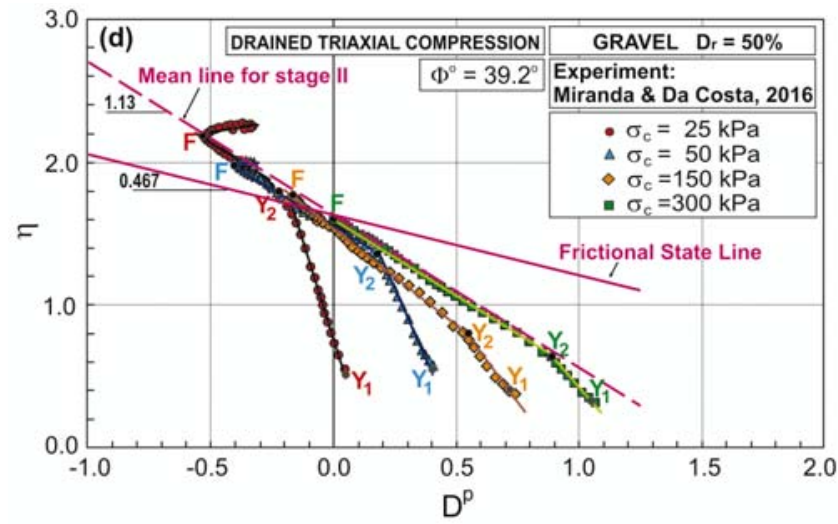



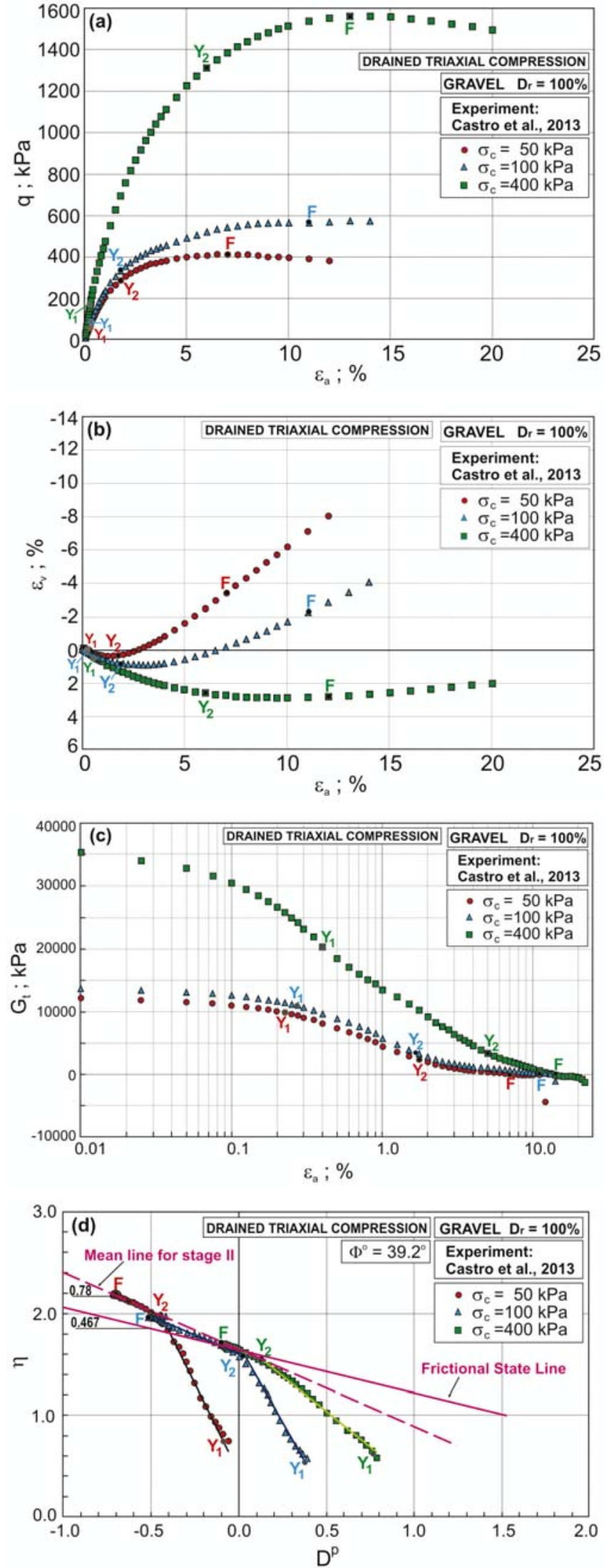

FIGURE 4. Relationships for dense gravel: $\mathrm{a}-q-\varepsilon_{a} ; \mathrm{b}-\varepsilon_{v}-\varepsilon_{a} ; \mathrm{c}-G_{t}-\varepsilon_{a}$; $\mathrm{d}-\eta-D^{p}$ 
of shearing $\left(\varepsilon_{a}<0.15 \%\right)$ almost for all tests. The stage $I$ is also realized at a narrow range of shear strains. At a wide range of shear strains the elastic parts of volumetric and shear strains increments are small comparing to global strains increments and may be negligible in stress-dilatancy analysis.

At stage II almost for all tests $\alpha_{2} \approx 0$ and for $\mathrm{D}_{\mathrm{r}}=35 \%, \beta_{2}=1.8(A=0.84)$ and $\mathrm{D}_{\mathrm{r}}=100 \%, \beta_{2}=1.67(A=0.78)$. For $\mathrm{D}_{\mathrm{r}}=50 \% \alpha_{2} \approx 0$ and $\beta_{2}=2.43(A=1.13)$. For gravel, treated as a special badly graded uncemented soil in this stage the initial structure (fabric) is destroyed and fully frictional behaviour $(\alpha=0, \beta=1)$ should be observed. In the author's opinion, at this stage $\beta>1$ is due to grain breakage. The grain breakage influences energy consumption and compaction of soil during shear.

The post-failure behaviour of gravel is different in various experiments. This is probably due to shear band formation at the failure point and non-homogeneous deformation in the sample.

It may be noticed that critical state may not be simply reached in conventional drained triaxial tests.

\section{CONCLUSIONS}

Frictional State Theory may be used to describe stress-plastic dilatancy relationships of gravel. The stress-plastic dilatancy relationship shows characteristic points and stages of shearing. These characteristic points and stages may not be simply visible in $q-\varepsilon_{a}, \varepsilon_{v}-\varepsilon_{a}$ relationships that are commonly presented in literature.

The value of critical frictional stage angle $\Phi^{\circ}$ parameters $\alpha$ and $\beta$ can be simply defined for all stages of shearing. The parameters $\alpha$ and $\beta$ represent not only real behaviour of soil during shear but also the stability of experimental technique, approximation and any undefined errors. The different mode tests at different stress and strain paths are required to describe the real behaviour of soil.

More research is needed to finally prove the correctness of Frictional State Theory and its use for soil modelling in the future.

\section{Acknowledgements}

This work, conducted at Bialystok University of Technology, was supported by Polish Financial Resources on Science under project $\mathrm{S} / \mathrm{WBiIS} / 2 / 2018$.

\section{REFERENCES}

BERGADO D.T., LAM F.I. 1987: Full scale load test of granular piles with different densities different properties of gravel and sand on soft Bangkok clay. Soils Found. 27 (1): 86-93.

CASTRO J., CIMENTADA A., Da COSTA A., CAÑIZAL J., SAGASETA C. 2013: Consolidation and deformation around stone columns: Comparison of theoretical and laboratory results. Comp. Geotech. 49: 326-337.

CIMENTADA A., Da COSTA A., CAÑIZAL J., SAGASETA C. 2011: Laboratory study on radial consolidation and deformation in day reinforced with stone columns. Can. Geotech. J. 48 (1): 36-52.

COOP M.R., WILLSON S.M. 2003: Behaviour of Hydrocarbon Reservoir Sands and Sandstones. Journal of Geotechnical and Geoenvironmental Engineering 129 (11): 1010-1019.

DOŁŻYK-SZYPCIO K. 2018: Stress-dilatancy for railway ballast. Stud. Geotech. Mech. [in print].

HONG Y.S. 2012: Performance of encased stone columns considering shear induced volumetric dilation of the fill material. Geosynth. Int. 19 (6): 438-452. 
LIU S. 2009: Application of in situ direct shear device to shear strength measurement of rockfill materials. Water Sci. Eng. 2 (3): 48-57.

MIRANDA M. 2017: Influence of geotextile encasement in triaxial tests on gravel. In: Proceedings of 19th International Conference on Soil Mechanics And Geotechnical Engineering, Seoul: 2595-2598.

MIRANDA M., Da COSTA A., CASTRO J., SAGASETA C. 2015: Influence of gravel density in the behaviour of soft soils improved with stone columns. Can. Geotech. J. 52: 1968-1980 .

MIRANDA M., Da COSTA A. 2016: Laboratory analysis of encased stone columns. Geotex. Geomemb. 44: 269-277.

SZYPCIO Z. 2016a: Stress-dilatancy for soils. Part I: The frictional state theory. Stud. Geotech. Mech. 38 (4): 51-57.

SZYPCIO Z. 2016b: Stress-dilatancy for soils. Part II: Experimental validation for triaxial tests. Stud. Geotech. Mech. 38 (4): 59-65.

Streszczenie: Naprężenia - dylatacja żwiru $w$ badaniach trójosiowego ściskania. W pracy przedstawiono zależność naprężenia od dylata- cji żwiru w badaniach trójosiowego ściskania, analizując wyniki badań opisanych w literaturze i stosując teorię stanów tarciowych (ang. Frictional State Theory). Charakterystyczne punkty i stany ścinania zdefiniowano, analizując zależność naprężeń od plastycznej dylatacji $\left(\eta-D^{p}\right)$. Pokazano, że charakterystyczne punkty i stany ścinania nie mogą być zidentyfikowane na krzywych zmian naprężeń i odkształceń objętościowych zwykle prezentowanych w literaturze.

Stowa kluczowe: grunty sypkie, żwiry, dylatacja, stany tarciowe

\section{MS received 27.01.2018}

MS accepted 04.06.2018

\section{Author's address:}

Zenon Szypcio

Wydział Budownictwa i Inżynierii Środowiska

Politechnika Białostocka

ul. Wiejska 45E, 15-351 Białystok

Poland

e-mail: z.szypcio@pb.edu.pl 